\title{
FAKTOR - FAKTOR YANG MEMPENGARUHI KINERJA KEUANGAN PEMERINTAH KABUPATEN/KOTA DI PROVINSI SUMATERA SELATAN TAHUN 2012-2015
}

\author{
Nyayu Miftahul Ilmiyyah ${ }^{1)}$, Evada Dewata ${ }^{2)}$, Sarikadarwati \\ 1) ilmiyyah.soul09@gmail.com, ${ }^{2}$ evada_polsri@yahoo.co.id \\ Jurusan Akuntansi Program Studi Akuntansi Sektor Publik Politeknik Negeri Sriwijaya
}

\begin{abstract}
The purpose of this research was to determine factors that influence the financial performance of regency/city in south of Sumatera province 2012-2015. Independent variable of this research were audit opinion, legislative, intergovernmental revenue, size, leverage, and cluster of local financial capacity. The samples used were as many as 15 regencies/cities using purposive sampling method. Datas were collected by using the method of documentation. This research result showed that audit opinion, legislative, intergovernmental revenue, size, leverage, and cluster of local financial capacity gave a significant influence on financial performance of regency/city that was measured based on the independence rate ratio. Partially, audit opinion, legislative, size, leverage, and cluster of local financial capacity variables did not give a significant influence on financial performance of regency/city but intergovernmental revenue variable gave a negative significant influence on financial performance of regency/city.
\end{abstract}

Keywords: Financial Performance, Audit Opinion, Legislative, Intergovernmental Revenue, Size, Leverage, and Cluster of Local Financial Capacity

\begin{abstract}
ABSTRAK
Penelitian ini dilakukan dengan tujuan mengetahui faktor-faktor yang mempengaruhi kinerja keuangan pemerintah daerah kabupaten/kota di Provinsi Sumatera Selatan pada tahun 20122015. Variabel penelitian yang digunakan adalah kinerja keuangan pemerintah daerah, opini audit, ukuran legislatif, intergovernmental revenue, size, leverage, dan klaster kemampuan keuangan daerah. sampel yang digunakan adalah sebanyak 15 kabupaten/kota dengan menggunakan metode purposive sampling. Data dikumpulkan dengan menggunakan metode dokumentasi. Hasil penelitian ini menunjukkan secara simultan variabel-variabel independen yaitu opini audit, ukuran legislatif, intergovernmental revenue, size, leverage, dan klaster kemampuan keuangan daerah secara bersama-sama memiliki pengaruh signifikan terhadap kinerja keuangan pemerintah daerah yang diukur dengan tingkat kemandirian daerah. Sedangkan secara parsial, variabel opini audit, ukuran legislatif, size, leverage, dan klaster kemampuan keuangan daerah tidak berpengaruh terhadap kinerja keuangan pemerintah daerah Sedangkan variabel intergovernmental revenue berpengaruh negatif terhadap kinerja keuangan pemerintah daerah.
\end{abstract}

Kata kunci: Opini Audit, Ukuran Legislatif, Intergovernmental Revenue, Size, Leverage, dan Klaster Kemampuan Keuangan Daerah 


\section{PENDAHULUAN}

Pertumbuhan ekonomi yang tinggi dengan sistem pemerintahan sentralistik selama pemerintahan orde baru ternyata rapuh dan menciptakan kesenjangan ekonomi serta kemiskinan yang besar. Kondisi tersebut diperparah oleh krisis ekonomi yang menyebabkan kualitas pelayanan publik terganggu dan seluruh sektor perekonomian, sehingga mengakibatkan krisis kepercayaan terhadap pemerintah (Muhayanah, 2016). Undang-Undang Nomor 23 Tahun 2014 tentang Pemerintah Daerah, UndangUndang Nomor 33 Tahun 2004 tentang Perimbangan Keuangan antara Pemerintah Pusat dan Pemerintah Daerah serta undang-undang sebelumnya mengenai pemerintah daerah telah memberikan perubahan dalam pemerintahan dari sentralisasi menjadi desentralisasi. Berdasarkan pasal 1 ayat (8) UU No. 23 Tahun 2014 desentralisasi merupakan penyerahan urusan pemerintahan oleh pemerintah pusat kepada daerah otonom berdasarkan asas otonomi. Menurut Undang-Undang No. 33 Tahun 2004, tentang Perimbangan Keuangan antara Pemerintah Daerah dan Pusat dalam Penyelenggaraan Otonomi Daerah diperlukan pengaturan, pembagian, dan pemanfaatan sumber daya nasional yang berkeadilan serta perimbangan keuangan pemerintah pusat dan daerah. Sumber pembiayaan pelaksanan desentralisasi terdiri dari pendapatan asli daerah, dana perimbangan, pinjaman daerah, dan lainlain penerimaan yang sah (Saputra, Suwendra, dan Yudiatmaja, 2016). Kewenangan mengelola potensi daerah masing-masing untuk membiayai urusan daerah dilaksanakan dalam wadah Pendapatan Asli Daerah (PAD). Menurut
Susilowati, Suharno, dan Kristianto (2016) dalam menjalankan otonomi daerah, Pemerintah Daerah dituntut untuk menjalankan roda pemerintahan yang efektif dan efisien, sehingga mampu mendorong masyarakat untuk berperan serta dalam melaksanakan pembangunan. Pemerintah Daerah juga dituntut untuk meningkatkan pemerataan dan keadilan, sehingga dapat mengembangkan seluruh potensi yang dimiliki oleh masing-masing daerah.

Peraturan Pemerintah Nomor 29 Tahun 2014 tentang Sistem Akuntabilitas Kinerja Instansi Pemerintah mengungkapkan bahwa kinerja adalah keluaran/hasil dari kegiatan/ program yang telah atau hendak dicapai sehubungan dengan penggunaan anggaran dengan kuantitas dan kualitas terukur. Menganalisis kinerja pemerintah daerah dalam mengelola keuangan daerahnya dapat dilakukan dengan analisis rasio keuangan terhadap Laporan Keuangan Pemerintah Daerah (LKPD). Rasio tingkat kemandirian daerah adalah salah satu analisis yang dapat menggambarkan kinerja keuangan pemerintah daerah. Daerah yang memiliki tingkat kemandirian yang tinggi berarti memiliki kemampuan dalam membiayai penyelenggaraan pemerintahan daerah dengan mengelolah potensi daerah menjadi sumber pendapatannya. Sumber pendanaan penyelenggaraan kegiatan dan aktifitas pemerintah berarti diperoleh secara mandiri dengan memanfaatkan sumber daya yang dimiliki oleh daerah tersebut.

$$
\text { Berdasarkan Postur Anggaran }
$$
Pendapatan dan Belanja Daerah (APBD) pada tahun 2015 komposisi pendapatan daerah untuk provinsi dan kabupaten/kota di Indonesia masih didominasi oleh dana perimbangan yaitu sebesar 55,93\%, 
sedangkan Pendapatan Asli Daerah (PAD) dan lain-lain pendapatan daerah yang sah hanya sebesar $24,11 \%$ dan $19,96 \%$. Hal ini mengindikasi masih banyaknya daerah di Indonesia yang belum mampu menyelenggarakan desentralisasi secara optimal terutama dalam memanfaatkan potensi daerah dalam meningkatkan pendapatan asli daerahnya (http://keuda.kemendagri.go.id). .

Provinsi Sumatera Selatan dengan luas daerah sebesar $91.592,43 \mathrm{~km}^{2}$ dan terdiri dari 17 Kabupaten/Kota, Berdasarkan data yang diperoleh dari Badan Pemeriksa Keuangan Republik Indonesia (BPK RI), kinerja keuangan Kabupaten/Kota di Sumatera Selatan belum menunjukan hasil yang optimal dalam empat tahun terakhir yaitu tahun 2012 hingga 2015. tingkat kemandirian tertinggi dari 17 kabupaten/kota di Provinsi Sumatera Selatan selama 4 tahun hanya mencapai 35,0\% yang dimiliki oleh Kota Palembang pada tahun 2014. Sedangkan tingkat kemandirian terendah adalah 2,4\% yang dimiliki oleh Kabupaten Ogan Ilir (OI) pada tahun 2013. Berdasarkan hal tersebut dapat diketahui bahwa kinerja keuangan pemerintah kabupaten/Kota di Provinsi Sumatera Selatan pada tahun 2012 hingga 2015 masih menunjukan kinerja keuangan yang rendah.

Pengukuran kinerja keuangan dilakukan dengan menggunakan informasi yang tersedia di dalam Laporan Keuangan Pemerintah Daerah (LKPD). LKPD merupakan bentuk pertanggungjawaban pemerintah daerah. Informasi yang disajikan dalam pelaporan keuangan harus memenuhi karakteristik kualitatif agar informasi yang disajikan berguna dan bermanfaat bagi pihak-pihak yang berkepentingan, sehingga dapat digunakan dalam pengambilan keputusan. Untuk memenuhi karakteristik kualitatif maka informasi dalam laporan keuangan harus disajikan secara wajar berdasarkan prinsip akuntansi yang berlaku umum. Oleh karena itu perlu dilakukan pemeriksaan atas laporan keuangan yang dimaksudkan untuk menilai kewajaran laporan keuangan berdasarkan prinsip akuntansi yang berlaku umum di Indonesia (Siregar, 2012). Badan Pemeriksa Keuangan (BPK) adalah lembaga pemeriksa keuangan Republik Indonesia. BPK merupakan lembaga independen yang akan melakukan pemeriksaan terhadap Laporan Keuangan Pemerintah Daerah (LKPD). Seluruh pemeriksaan BPK RI dilakukan dalam rangka mendorong terwujudnya transparansi dan akuntabilitas keuangan negara. Untuk mewujudkan akuntabilitas, tidak cukup dengan akuntabilitas keuangan saja, sementara akuntabilitas kinerja ditinggalkan, atau sebaliknya. Keduaduanya harus diwujudkan, dengan demikian dalam pengelolaan keuangan negara, bagi entitas tidak cukup jika sudah memperoleh opini WTP dalam laporan keuangannya, karena opini WTP bukanlah segala-galanya, artinya upaya memperoleh opini WTP hendaknya seiring dengan upaya mencapai kinerja yang baik dalam pengelolaan keuangan. Idealnya upaya untuk meraih opini WTP juga dibarengi dengan upaya untuk mencapai kinerja terbaik, tidak terjadi korupsi, dan rakyatnya makin sejahtera (Badan Pemeriksa Keuangan, 2015).

Kineja keuangan pemerintah daerah dapat dipengaruhi oleh beberapa faktor, seperti yang diungkap oleh beberapa peneliti dalam penelitiannya. Noviyanti dan Kiswanto (2016) dan Sudarsana dan Rahardjo (2013) menunjukan bahwa fungsi pengawasan 
DPRD, intergovernmental revenue, dan ukuran daerah secara bersama-sama dapat mempengaruhi kinerja keuangan pemerintah. Penelitian Darmanto (2012) yang juga menunjukan bahwa variabel size dan leverage yang berpengaruh secara bersama-sama terhadap kinerja keuangan pemerintah daerah serta Suryaningsih dan Sisdyani (2016) yang menyatakan bahwa secara simultan opini audit dan intergovernmental revenue berpengaruh terhadap kinerja keuangan pemerintah daerah. Permendagri Nomor 21 Tahun 2007 tentang Pengelompokan Kemampuan Keuangan Daerah, Penganggaran dan Pertanggungjawaban Penggunaan Belanja Penunjang Operasional Pimpinan Dewan Perwakilan Rakyat Daerah serta Tata Cara Pengembalian Tunjangan Komunikasi Intensif dan Dana Operasional menyatakan pada Pasal 2 bahwa kemampuan daerah terdiri dari 3 (tiga) kelompok (klaster) yaitu tinggi, sedang, dan rendah. Diduga tinggi rendahnya klaster daerah dapat mempengaruhi kinerja keuangan pemerintah daerah.

Berdasarkan latar belakang diatas maka perumusan masalah dalam penelitian ini adalah apakah opini audit, ukuran legislatif, intergovermental revenue, size, leverage, dan klaster kemampuan keuangan daerah berpengaruh baik secara parsial maupun simultan terhadap kinerja keuangan pemerintah daerah. adapun tujuan penelitian ini adalah untuk mengetahui pengaruh opini audit, ukuran legislatif, intergovermental revenue, size, leverage, dan klaster kemampuan keuangan terhadap kinerja keuangan pemerintah daerah baik secara parsial maupun simultan. hasil penelitian ini dapat memberikan kontribusi pengetahuan pada bidang Akuntansi khususnya Akuntansi Sektor Publik yang berkaitan dengan kinerja keuangan pemerintah daerah serta bagi pemerintah dan masyarakat terkait kinerja keuangan pemerintah daerah.

\section{KERANGKA TEORITIS DAN PENGEMBANGAN HIPOTESIS}

Tuntutan yang tinggi terhadap kinerja dan akuntabilitas kinerja daerah ini berujung pada kebutuhan pengukuran kinerja pemerintah daerah, untuk itu pemerintah dituntut untuk mampu membangun ukuran kinerja yang baik. Pengukuran kinerja berfungsi untuk menilai sukses atau tidaknya suatu organisasi, program, atau kegiatan. Pengukuran kinerja diperlukan untuk menilai tingkat besarnya terjadi penyimpangan antara kinerja aktual dan kinerja yang diharapkan. Dengan mengetahui penyimpangan tersebut, dapat dilakukan upaya perbaikan dan peningkatan kinerja (Rai, 2008:17). Pengukuran kinerja organisasi publik selain dapat dilihat dari aspek kinerja nonkeuangan namun juga dapat dilihat melalui aspek keuangan. Gambaran kinerja keuangan dapat diketahui dengan melakukan analisis laporan keuangan pemerintah daerah. analisis laporan keuangan merupakan kegiatan untuk menginterpretasikan angka-angka pada laporan keuangan dalam rangka menilai kinerja keuangan yang hasil analisis tersebut akan digunakan sebagai dasar pengambilan keputusan ekonomi, sosial, atau politik (Mahmudi, 2016:89). Salah satu yang dapat dilakukan untuk menilai kinerja keuangan pemerintah daerah adalah dengan menggunakan analisis rasio keuangan berupa rasio kemandirian daerah, rasio ketergantungan daerah, desentralisasi fiskal, efisiensi dan efektifitas PAD, efisiensi dan efektifitas pajak daerah, derajat kontribusi BUMD, 
rasio kemampuan mengembalikan pinjaman (Debt Service Coverage Ratio), dan rasio utang terhadap belanja. Rasio kemandirian keuangan daerah menunjukkan kemampuan pemerintah daerah dalam membiayai sendiri kegiatan pemerintahan, pembangunan dan pelayanan kepada masyarakat (Heriningsih dan Marita, 2013:4). Rasio kemandirian keuangan daerah dihitung dengan cara membandingkan jumlah penerimaan Pendapatan Asli Daerah dibagi dengam jumlah pendapatan bantuan dari pemerintah pusat dan provinsi serta pinjaman daerah. semakin tinggi angka rasio ini menunjukan pemerintah daerah semakin tinggi kemandirian keuangan daerahnya.

Badan Pemeriksa Keuangan (BPK) mempunyai tugas dan kewenangan untuk melakukan pemeriksaan terhadap instansi pemerintah daerah setiap tahun. Hasil audit yang berupa opini seringkali dijadikan sebagai pengukur kinerja pemerintah daerah. Ada 5 jenis opini yang dapat dikeluarkan oleh BPK, yaitu Wajar Tanpa Pengecualian (WTP), Wajar Tanpa Pengecualian dengan Paragraf Penjelasan (WTP DPP), Wajar Dengan Pengecualian (WDP), Tidak Wajar (TW), dan Tidak Memberi Pendapat (TMP), Setiap pemerintah daerah selalu berusaha untuk meraih dan mempertahankan opini WTP, karena dengan mendapatkan opini ini maka kinerja keuangan pemerintah daerah dianggap baik. Hal ini sesuai dengan hasil penelitian yang dilakukan oleh Masdiantini dan Erawati (2016) yang mengungkapkan bahwa ada pengaruh positif signifikan opini audit BPK pada kinerja keuangan pemerintah kabupaten/kota se-Bali. Semakin baik opini audit BPK yang diperoleh pemerintah daerah.
Pengawasan dan pemeriksaan merupakan faktor - faktor penting dalam peningkatan kinerja suatu pemerintah daerah. pengawasan dilakukan oleh lembaga legislatif yaitu Dewan Perwakilan Rakyat Daerah (DPRD). Tujuan dari fungsi pengawasan adalah agar pemerintah daerah dapat mengalokasikan anggaran yang ada dan dapat digunakan dengan sebagaimana mestinya. Pengawasan yang dilakukan oleh DPRD diharapkan dapat membantu dan memastikan pemerintah daerah dalam memenuhi kewajibannya dalam hal pelayanan publik dan mensejahterakan masyarakat. Anggota DPRD memiliki tugas untuk melakukan peningkatan pengawasan terhadap pemerintah daerah sehingga berdampak pada peningkatan kinerja pemerintah daerah. hal ini sejalan dengan yang diungkap oleh Noviyanti dan Kiswanto (2016) bahwa jumlah anggota DPR yang banyak diharapkan dapat meningkatkan kinerja pemerintah daerah melalui adanya pengawasan yang efektif.

Dana Alokasi Umum (DAU) merupakan cerminan dari Intergovermental revenue (tingkat ketergantungan pemerintah daerah pada pemerintah pusat). Berdasarkan UndangUndang Republik Indonesia Nomor 33 Tahun 2004 tentang Perimbangan Keuangan antara Pemerintah Pusat dan Pemerintah Daerah pasal 1 ayat 21, Dana Alokasi Umum, selanjutnya disebut DAU adalah dana yang bersumber dari pendapatan APBN yang dialokasikan dengan tujuan pemerataan kemampuan keuangan antar-Daerah untuk mendanai kebutuhan Daerah dalam rangka pelaksanaan Desentralisasi. DAU diberikan pemerintah pusat untuk membiayai kekurangan dari pemerintah daerah dalam memanfaatkan PAD-nya. 
DAU ini bersifat Block Grant yang artinya penggunaan DAU diserahkan kepada pemerintah daerah sesuai dengan prioritas, kepentingan, dan kebutuhan daerah masing-masing yang bertujuan untuk meningkatkan pelayanan publik dalam rangka melaksanakan otonomi daerah. Pemerintah pusat akan memantau pelaksaanaan alokasi DAU sehingga dapat memacu pemerintah daerah agar meningkatkan kinerja keuangannya (Noviyanti dan Kiswato, 2016).

Pemerintah daerah adalah pemegang peran utama dalam memberikan pelayanan kepada masyarakat. Menjamin kesejahteraan masyarakat melalui pelayanan publik adalah tugas wajib dari pemerintah daerah. pemerintah yang kinerja keuangannya baik akan memiliki tingkat pelayanan publik yang baik. Pemenuhan terhadap pelayanan publik yang baik bagi masyarakat harus didukung dengan aset yang baik pula. Jumlah aset yang dimiliki oleh suatu daerah akan menunjukan seberapa besar ukuran daerah tersebut. Daerah yang memiliki ukuran daerah atau total aset yang lebih besar akan memberikan keuntungan berupa kemudahan dalam kegiatan operasional sehingga pemerintah daerah dalam memberikan pelayanan kepada masyarakat akan maksimal. Pemerintah daerah yang memiliki ukuran besar dituntut untuk memiliki kinerja yang lebih baik.

Leverage merupakan besarnya aset daerah yang dibiayai oleh utang karena daerah tidak mampu membiayai urusan daerahnya melalui modal sendiri. Menurut Darmanto (2012), leverage yang merupakan faktor finansial mempengaruhi kinerja keuangan pemerintah daerah mengindikadsi bahwa semakin tinggi tingkat leverage yang dimiliki oleh pemerintah daerah, maka pengawasan dari pihak kreditor juga akan menjadi lebih ketat untuk menjamin pengembalian dana yang dipinjamkan, pengawasan yang lebih ketat tersebut akan mendorong pemerintah daerah untu memperbaiki kinerja keuangan mereka.

Kelompok kemampuan keuangan daerah adalah klasifikasi/klaster suatu daerah untuk menentukan kelompok kemampuan keuangan daerah tertentu yang ditetapkan dengan formula sebagai dasar penghitungan besaran Tunjangan Komunikasi Intensif dan Belanja Penunjang Operasional Pimpinan pada setiap klaster. Klaster keuangan daerah menurut Permendagri No. 21 Tahun 2007 dibagi menjadi 3 yaitu tinggi (Klaster a), sedang (Kalster b), Rendah (Klaster c). Menurut pasal 5 Pengelompokan kemampuan keuangan daerah untuk kabupaten/kota pada klaster a adalah di atas Rp.400.000.000.000,00 (empat ratus milyar rupiah), untuk klaster b kemampuan keuangan diantara Rp.200.000.000.000,00 (dua ratus milyar) sampai dengan Rp.400.000.000.000,00 (empat ratus milyar rupiah), sedangkan klaster c adalah di bawah Rp.200.000.000.000,00 (dua ratus milyar). Berdasarkan permendagri tersebut, ketika suatu daerah berada pada klaster yang tinggi hal itu menunjukan kemampuan keuangan yang juga tinggi dan tentunya diharapkan pula dapat meningkatkan kinerja keuangan pemerintah daerah. Sehingga hubungan logis diantaranya adalah semakin tinggi klaster kemampuan keuangan daerah maka semakin tinggi kinerja keuangan pemerintah daerah.

Kabupaten/Kota yang mendapatkan opini Wajar Tanpa Pengecualian (WTP), jumlah anggota legislatif yang banyak, tingkat ketergantungan yang rendah, ukuran daerah yang besar, tingkat utang 
yang kecil serta klaster kemampuan daerah yang tinggi diharapkan dapat menjadi meningkatkan kinerja keuangan pemerintah daerahnya. Dari penjelasan diatas maka dapat dirumuskan hipotesis penelitian ini sebagai berikut:

$\mathrm{H}_{1}$ : Opini Audit berpengaruh terhadap kinerja keuangan pemerintah daerah.

$\mathrm{H}_{2}$ : Ukuran legislatif berpengaruh terhadap kinerja keuangan pemerintah daerah.

$\mathrm{H}_{3}$ : Intergovermental revenue berpengaruh terhadap kinerja keuangan pemerintah daerah.

$\mathrm{H}_{4}$ : Size berpengaruh terhadap kinerja keuangan pemerintah daerah

$\mathrm{H}_{5}$ : Leverage berpengaruh terhadap kinerja keuangan pemerintah daerah.

$\mathrm{H}_{6}$ : Klaster kemampuan keuangan daerah berpengaruh terhadap kinerja keuangan pemerintah daerah.

$\mathrm{H}_{7}$ : Opini Audit, Ukuran Legislatif, Intergovernmental Revenue, Size, Leverage, dan Klaster kemampuan keuangan daerah secara simultan berpengaruh terhadap kinerja keuangan pemerintah daerah.

Dari penjelasan maka kerangka pemikiran penelitian dapat digambarkan sebagai berikut:

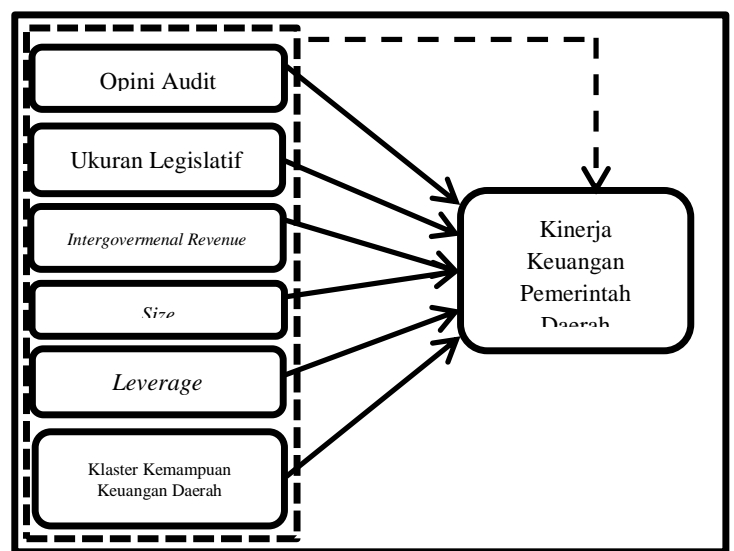

\section{Gambar 1 \\ Kerangka Pemikiran}

Keterangan:

$\longrightarrow \quad$ : Pengaruh variabel secara

parsial.

$---\rightarrow \quad$ : Pengaruh variabel secara

simultan.

METODE PENELITIAN

Populasi, Sampel, dan teknik pengambilan sampel

Populasi penelitian ini adalah pemerintah daerah kabupaten/kota di Provinsi Sumatera Selatan pada tahun 2012-2015. Adapun jenis data yang digunakan dalam penelitian ini adalah data sekunder. Metode pengambilan sampel adalah purposive sampling. Kriteria pengambilan sampel disajikan pada tabel 1.

Tabel 1

Populasi dan sampel

\begin{tabular}{|c|l|c|}
\hline No. & \multicolumn{1}{|c|}{ Identifikasi } & $\begin{array}{c}\text { Jumlah } \\
\text { Pemerintah } \\
\text { Daerah }\end{array}$ \\
\hline 1 & $\begin{array}{l}\text { Kabupaten/kota di Provinsi Sumatera selatan yang } \\
\text { telah diaudit BPK tahun 2012 - 2015 }\end{array}$ & 17 \\
\hline 2 & $\begin{array}{l}\text { Kabupaten/kota di Provinsi Sumatera yang telah di } \\
\text { audit BPK yang tidak memiliki LKPD secara lengkap } \\
\text { selama tahun 2012 - 2015 }\end{array}$ & $(2)$ \\
\hline 3 & $\begin{array}{l}\text { Kabupaten/Kota yang tidak memiliki informasi } \\
\text { Keuangan dibutuhkan secara lengkap }\end{array}$ & $(0)$ \\
\hline 4 & $\begin{array}{l}\text { Jumlah Kabupaten/kota di Provinsi Sumatera selatan } \\
\text { yang digunakan sebagai sampel }\end{array}$ & 15 \\
\hline 5 & Jumlah tahun penelitian & 4 \\
\hline & \multicolumn{1}{|c|}{ Jumlah unit analisis } & 60 \\
\hline
\end{tabular}

Variable Penelitian:

Variabel dependen dalam

penelitian ini adalah Kinerja Keuangan Pemerintah. variabel independen yang digunakan adalah opini audit, ukuran legislatif, intergovermental revenue, size, leverage, dan klaster kemampuan keuangan daerah. Penjelasan mengenai definisi operasional dan pengukuran dari masing-masing variabel akan dijelaskan pada Tabel 2 : 
Tabel 2

Operasional Variabel Penelitian

\begin{tabular}{|c|c|c|c|}
\hline VARIABEL & INDIKATOR & SUMBER DATA & SKALA \\
\hline \multicolumn{4}{|l|}{ Variabel Dependen } \\
\hline Kinerja Keungan Pemerintah Daerah (Y) & $\begin{array}{c}\text { PAD/Bantuan } \\
\text { Pusat/Provinsi }+ \\
\text { Pinjaman } \\
\end{array}$ & $\begin{array}{c}\text { LHP Tahun 2012-2015 dari Pusat } \\
\text { Informasi dan Komunikasi (PIK) } \\
\text { BPK }\end{array}$ & Rasio \\
\hline \multicolumn{4}{|l|}{ Variabel Independen } \\
\hline \multirow{5}{*}{ Opini Audit (X1) } & $5=\mathrm{WTP}$ & \multirow{5}{*}{ IHPS I tahun 2016} & \multirow{5}{*}{ Interval } \\
\hline & 4 = WTP DPP & & \\
\hline & $3=\mathrm{WDP}$ & & \\
\hline & 2 = Tidak Wajar & & \\
\hline & $1=$ Disclaimer & & \\
\hline Ukuran Legislatif (X2) & Jumlah Anggota DPRD & Jumlah Anggota DPRD & Rasio \\
\hline Intergovermental Revenue (X3) & DAU/Total Pendapatan & $\begin{array}{c}\text { LHP Tahun 2012-2015 dari Pusat } \\
\text { Informasi dan Komunikasi (PIK) } \\
\text { BPK }\end{array}$ & Rasio \\
\hline Ukuran Daerah (Size) (X4) & Ln Total Aset & $\begin{array}{c}\text { LHP Tahun 2012-2015 dari Pusat } \\
\text { Informasi dan Komunikasi (PIK) } \\
\text { BPK }\end{array}$ & Rasio \\
\hline Leverage (X5) & Debt/Equity & $\begin{array}{c}\text { LHP Tahun 2012-2015 dari Pusat } \\
\text { Informasi dan Komunikasi (PIK) } \\
\text { BPK }\end{array}$ & Rasio \\
\hline \multirow{3}{*}{ Klaster Kemampuan Keuangan Daerah (X6) } & $\begin{aligned} 2= & \text { Klaster A } \\
& (>400 \text { Milyar })\end{aligned}$ & \multirow{3}{*}{$\begin{array}{c}\text { LHP Tahun 2012-2015 dari Pusat } \\
\text { Informasi dan Komunikasi (PIK) } \\
\text { BPK }\end{array}$} & \multirow{3}{*}{ Interval } \\
\hline & $\begin{aligned} 1= & \text { Kalster B } \\
& (200 \text { Milyar }- \\
& 400 \text { Milyar })\end{aligned}$ & & \\
\hline & $\begin{aligned} 0= & \text { Klaster C } \\
& (<200 \text { Milyar })\end{aligned}$ & & \\
\hline
\end{tabular}

\section{Metode Analisis}

Analisis data dalam penelitian ini dilakukan dengan menggunakan uji asumsi klasik dan hasil dari data penelitian menunjukkan bahwa residual data penelitian terdistribusi normal, bebas dari multikolinearitas dan bebas dari heteroskedastisitas namun terdapat masalah autokorelasi sehingga perlu adanya tindakan untuk mengatasi autokorelasi sebelum dilakukan analisis regresi linear berganda. Penulis menggunakan metode Cochrane Orcutt dengan 2 kali tranformasi data ke dalam bentuk Lag sehingga sampel berkurang sebanyak 2 sampel dan data terbebas dari autokorelasi.

\section{HASIL DAN PEMBAHASAN}

Statistik deskriptif dalam penelitian pada dasarnya merupakan proses transformasi data penelitian dalam bentuk tabulasi sehingga mudah dipahami dan diinterpretasikan. Statistik deskriptif memberikan deskripsi suatu data yang 
dilihat dari rata rata (mean), standar deviasi (standard deviation), dan maksimum minimum. Hasil analisis deskriptif dapat dilihat pada Tabel 3 berikut ini:

\section{Tabel 3}

Statistik Deskriptif

\begin{tabular}{|l|l|r|r|r|r|}
\hline & $\mathrm{N}$ & Minimum & Maximum & Mean & Std. Deviation \\
\hline Kinerja Keuangan & 60 & 0,023 & 0,350 & 0,082 & 0,070 \\
Opini Audit & 60 & 1 & 5 & 4,23 & 1,047 \\
Ukuran Legislatif & 60 & 23 & 50 & 38,42 & 8,222 \\
Intergovernmental & 60 & 0,715 & 0,963 & 0,880 & 0,060 \\
Revenue & 60 & 0,892 & 10,218 & 3,327 & 1,935 \\
Size & 60 & 0,000 & 0,129 & 0,015 & 0,023 \\
Leverage & 60 & 1 & 2 & 1,63 & 0,486 \\
Klaster & & & & \\
Valid N (listwise) & 60 & & & \\
\hline
\end{tabular}

Sumber: Data diolah dengan SPSS 22 (2017)

Berdasarkan hasil statistik kabupaten Musi Banyuasin tahun 2014 deskriptif diatas dapat dilihat bahwa yaitu sejumlah Rp 10.218.372.549.719,5. kinerja keuangan pemerintah daerah terendah dimiliki oleh Kabupaten Ogan Ilir (OI) pada tahun 2013 dan kinerja keuangan pemerintah daerah tertinggi dimiliki oleh Kota Palembang pada tahun 2014. Nilai minimum atau opini audit terendah adalah 1 yaitu disclaimer (tidak memberikan pendapat) dan nilai maksimum atau opini tertinggi adalah 5 yaitu wajar tanpa pengecualian (WTP). Ukuran Legislatif memiliki jumlah terendah yaitu sejumlah 23 orang yang dimiliki oleh Kabupaten Lahat. Jumlah ukuran legislatif terbanyak adalah 50 orang yang dimiliki oleh Kota Palembang dari tahun 2012 hingga 2015 dan Kabupaten Ogan Komering Ulu Selatan (OKUS) pada tahun 2015. Nilai terendah dari Intergovernmental revenue sebesar 71,5\% diperoleh Kota Palembang pada tahun 2014. Sedangkan, nilai tertinggi Intergovernmental revenue terdapat pada Kabupaten Empat Lawang tahun 2012 dengan nilai sebesar 96,38\%. Size (ukuran daerah) terbesar dimiliki oleh Untuk Size terkecil terdapat pada Kabupaten Empat Lawang tahun 2012 dengan jumlah aset sebesar Rp 892.082.030.729,7. Nilai rasio leverage terendah dalam penelitian ini adalah 0,00\% yang dimiliki oleh Kabupaten Ogan Komering Ilir (OKI) pada tahun 2012, dan Kabupaten Ogan Komering Ulu Selatan pada tahun 2012 hingga 2014. Sedangkan nilai rasio leverage tertinggi adalah sebesar 12,99\% yang dimiliki oleh Kabupaten Ogan Ilir (OI) pada tahun 2015.

\section{Hasil Uji Hipotesis \\ Uji statistik $\mathbf{t}$}

Uji statistik $t$ bertujuan untuk mengetahui apakah secara parsial variabel independen atau opini audit, ukuran legislatif, intergovernmental revenue, size, Leverage, Klaster kemampuan keuangan daerah berpengaruh secara signifikan atau tidak terhadap variabel dependen atau kinerja keuangan pemerintah daerah. Berikut ini adalah hasil uji statistik $t$ dengan SPSS 22. 
Tabel 4

Hasil Uji Statistik $\mathbf{t}$

Coefficients $^{\mathrm{a}}$

\begin{tabular}{|c|c|c|c|c|c|c|}
\hline \multirow[b]{2}{*}{ Model } & \multicolumn{2}{|c|}{$\begin{array}{c}\text { Unstandardized } \\
\text { Coefficients }\end{array}$} & \multirow{2}{*}{$\begin{array}{c}\text { Standardized } \\
\text { Coefficients } \\
\text { Beta } \\
\end{array}$} & \multirow[b]{2}{*}{$\mathrm{t}$} & \multirow[b]{2}{*}{ Sig. } & \multirow[b]{2}{*}{ Kesimpulan } \\
\hline & $\mathrm{B}$ & $\begin{array}{l}\text { Std. } \\
\text { Error }\end{array}$ & & & & \\
\hline 1 (Constant) &,- 199 & 194 & & $-1,028$ & ,309 & \\
\hline Lag2_Opini & ,005 & ,005 &, 117 & 1,101 & ,276 & $\mathrm{H}_{1}=$ ditolak \\
\hline Lag2_ukuranLegislatif & ,001 &, 001 &, 124 & 993 & ,326 & $\mathrm{H}_{2}=$ ditolak \\
\hline $\begin{array}{l}\text { Lag2_Intergovernmental } \\
\text { Revenue }\end{array}$ &,- 417 & , 106 &,- 441 & $-3,940$ & ,000 & $\mathrm{H}_{3}=$ diterima \\
\hline Lag2_Size & ,033 & ,019 &, 228 & 1,704 & ,094 & $\mathrm{H}_{4}=$ ditolak \\
\hline Lag2_Leverage & ,248 & , 195 &, 125 & 1,276 & ,208 & $\mathrm{H}_{5}=$ ditolak \\
\hline Lag2_Klaster &, 004 &, 013 &, 035 & ,304 &, 762 & $\mathrm{H}_{6}=$ ditolak \\
\hline
\end{tabular}

a. Dependent Variable: Lag2_Kinerja

Sumber: Data diolah dengan SPSS 22 (2017)

Berdasarkan Tabel 4 di atas opini audit memiliki koefisien regresi 0,005. Nilai t hitung sebesar 1,101 yang lebih kecil dari titik kritis yaitu 2,008 dengan tingkat signifikansi sebesar 0,276, sehingga dapat disimpulkan bahwa opini audit tidak berpengaruh signifikan terhadap kinerja keuangan pemerintah daerah $\mathbf{H}_{1}$ ditolak. Berdasarkan hasil uji tersebut mengindikasi bahwa pemerintah daerah kabupaten/kota di Provinsi Sumatera Selatan belum terlalu memperhatikan hasil opini audit untuk memperbaiki kinerja keuangan pemerintah daerahnya. Sehingga meskipun kabupaten/kota di Provinsi Sumatera Selatan mendapatkan opini terbaik yaitu wajar tanpa pengecualian, hal ini tidak berpengaruh terhadap baik tidaknya kinerja keuangan pemerintah daerahnya. Hasil Penelitian ini sejalan dengan penelitian sebelumnya yang dilakukan oleh Marfiana dan Kurniasih (2013) yang menyatakan bahwa opini audit tidak berpengaruh terhadap kinerja keuangan pemerintah daerah. hasil penelitian ini berbeda dengan penelitian sebelumnya yang dilakukan oleh Masdiantini dan Erawati (2016) dan Suryaningsih dan Sisdyani (2016) yang menyatakan opini audit mempengaruhi kinerja keuangan. Semakin baik opini audit BPK yang diperoleh kabupaten/kota, maka dapat menunjukkan semakin baik kinerja pemerintah daerah atas pengelolaan keuangan daerah.

Hasil uji statistik t untuk variabel ukuran legislatif menunjukan angka koefisiensi sebesar 0,001. Nilai t hitung sebesar 0,993 lebih kecil dari titik kritis yaitu 2,008 dengan tingkat signifikansi sebesar 0,326, maka dapat disimpulkan bahwa ukuran legislatif tidak berpengaruh signifikan terhadap kinerja keuangan pemerintah daerah sehingga $\mathbf{H}_{2}$ ditolak. Hal ini dikarenakan kuantitas anggota DPRD yang besar belum cukup untuk memberikan pengaruh terhadap kinerja keuangan pemerintah daerah jika tidak didukung dengan kualitas kerja yang baik 
bagi setiap anggota DPRD dalam menjalankan tugas dan kewenangannya. Hasil penelitian ini mendukung penelitian sebelumnya yang dilakukan oleh Sesotyaningtyas (2012) dan Maiyora (2015) yang menyatakan bahwa ukuran legislatif tidak berpengaruh terhadap kinerja keuangan pemerintah daerah. Berbeda dengan penelitian sebelumnya yang dilakukan oleh Marfiana dan Kurniasih (2013) dan Noviyanti dan Kiswanto (2016) yang menyatakan ukuran legislatif mempengaruhi kinerja keuangan.

Hasil uji statistik t untuk variabel intergovernmental revenue menunjukan angka koefisiensi negatif sebesar -0,417. Nilai $\mathrm{t}$ hitung sebesar $-3,940$ dengan tingkat signifikansi sebesar 0,000. Karena Nilai t hitung lebih besar dari titik kritis 2.008 dan signifikansi lebih rendah dari 0,05 maka dapat disimpulkan bahwa intergovernmental revenue berpengaruh signifikan terhadap kinerja keuangan pemerintah daerah. sehingga $\mathbf{H}_{3}$ diterima. Hal ini mengindikasi semakin besarnya nilai intergovernmental revenue yang dimiliki oleh kabupaten/kota di Provinsi Sumatera Selatan maka semakin menurun kinerja keuangan yang diukur dengan tingkat kemandirian pemerintah daerah. Penelitian ini sejalan dengan penelitian sebelumnya yang dilakukan oleh Noviyanti dan Kiswanto (2016) , Aziz (2016), Suryaningsih dan Sisdyani (2016) dan Marfiana \& Kurniasih (2013) yang menyatakan bahwa Intergovernmental revenue berpengaruh negatif terhadap kinerja keuangan pemerintah daerah yang diukur dengan tingkat kemandirian daerah. Hasil penelitian ini tidak mendukung penelitian sebelumnya yang dilakukan oleh Masdiantini dan Erawati (2016), Sudarsana dan Rahardjo (2013) dan Sesotyaningtyas (2012) yang menyatakan
Intergovernmental revenue tidak mempengaruhi kinerja keuangan pemerintah daerah.

Hasil uji statistik $t$ untuk variabel size menunjukan angka koefisiensi sebesar 0,033. Nilai t hitung sebesar 1,704 lebih kecil dari titik kritis yaitu 2,008 dengan tingkat signifikansi sebesar 0,094, maka dapat disimpulkan bahwa size tidak berpengaruh signifikan terhadap kinerja keuangan pemerintah daerah sehingga $\mathbf{H}_{\mathbf{4}}$ ditolak. Hasil penelitian ini mengindikasi bahwa besar kecilnya total aset yang dimiliki oleh pemerintah daerah Kabupaten/kota di Provinsi Sumatera Selatan belum dapat dikatakan sebagai faktor yang mempengaruhi kenaikan ataupun penurunan kinerja keuangan. Hal ini disebabkan oleh bukan hanya jumlah aset yang besar, namun manajemen pemerintah daerah kabupaten/kota di Provinsi Sumatera Selatan juga harus mampu memanfaatkan dan mengelola aset yang dimiliki tersebut agar dapat memberikan sumber pendapatan bagi pemerintah daerah. Penelitian ini mendukung penelitian sebelumnya dilakukan oleh Darmanto (2012), Marfiana \& Kurniasih (2013), Sudarsana dan Rahardjo (2013), dan Noviyanti dan Kiswanto (2016) yang menyatakan bahwa size tidak berpengaruh terhadap kinerja keuangan pemerintah daerah. Hasil penelitian ini tidak mendukung penelitian sebelumnya yang dilakukan oleh Aziz (2016), Maiyora (2015), Renas (2014), dan Masdiantini dan Erawati (2016) yang menyatakan size mempengaruhi kinerja keuangan.

Hasil uji statistik $\mathrm{t}$ untuk variabel leverage menunjukan angka koefisiensi sebesar 0,248. Nilai t hitung sebesar 1,276 lebih kecil dari titik kritis yaitu 2,008 dengan tingkat signifikansi sebesar 0,208 
di atas 0,05, maka dapat disimpulkan bahwa leverage tidak berpengaruh signifikan terhadap kinerja keuangan pemerintah daerah sehingga dalam penelitian ini $\mathbf{H}_{5}$ ditolak. Hal ini disebabkan rendahnya rata-rata leverage yang dimiliki mengindikasi bahwa pemerintah daerah kabupaten/kota di Provinsi Sumatera Selatan tidak memperhatikan tingkat utang dalam memperbaiki kinerja keuangan pemerintah daerahnya. Hasil penelitian ini mendukung penelitian sebelumnya yang dilakukan oleh Sesotyaningtyas (2012) yang menyatakan bahwa leverage tidak berpengaruh terhadap kinerja keuangan pemerintah daerah. berbeda dengan penelitian sebelumnya yang dilakukan oleh Darmanto (2012) yang menyatakan leverage mempengaruhi kinerja keuangan.

Hasil uji statistik t untuk variabel klaster kemampuan keuangan daerah menunjukan angka koefisiensi sebesar 0,004. Nilai t hitung sebesar 0,304, lebih kecil dari t-tabel yaitu 2,008 dengan tingkat signifikansi sebesar 0,762 lebih besar dari 0,05, maka dapat disimpulkan bahwa klaster kemampuan keuangan daerah tidak berpengaruh signifikan terhadap kinerja keuangan pemerintah daerah dan Ho ditolak. Hal ini disebabkan karena pembagian klaster kemampuan keuangan daerah bertujuan untuk menentukan pembagian tunjangan bagi anggota DPRD. Permendagri Nomor 21 tahun 2007 pasal 1 ayat 7 kelompok kemampuan keuangan daerah adalah klasifikasi/klaster suatu daerah untuk menentukan kelompok kemampuan keuangan daerah tertentu yang ditetapkan dengan formula sebagai dasar penghitungan besaran Tunjangan Komunikasi Intensif (TKI) dan Belanja Penunjang Operasional (BPO) Pimpinan pada setiap klaster. Pasal 1 ayat 5 Permendagri tersebut menyatakan bahwa TKI adalah uang yang diberikan kepada Pimpinan dan Anggota DPRD setiap bulan dalam rangka mendorong peningkatan kinerja Pimpinan dan Anggota DPRD. Sedangkan BPO Pimpinan DPRD dalam pasal 1 ayat 6 adalah dana yang disediakan bagi Pimpinan DPRD setiap bulan untuk menunjang kegiatan operasional yang berkaitan dengan representasi, pelayanan, dan kebutuhan lain guna melancarkan pelaksanaan tugas Pimpinan DPRD seharihari. Sehingga diketahui bahwa pembagian klaster tiap daerah ditujukan untuk menentukan pembagian tunjangan bagi anggota DPRD. Daerah yang berada pada klaster kemampuan keuangan daerah yang tinggi akan memiliki nilai TKI dan BPO yang tinggi pula bagi tiap anggota DPRDnya, sehingga diharapkan dapat meningkatkan kualitas kerja bagi anggota DPRD dalam menjalankan setiap tugas dan kewenangannya. Oleh karena itu tinggi rendahnya klaster kemampuan keuangan daerah belum dapat memberikan pengaruh terhadap kinerja kuangan pemerintah daerah jika tidak didukung dengan kualitas kerja yang baik dari setiap anggota DPRD.

\section{Uji statistik F}

Uji statistik $F$ bertujuan untuk mengetahui apakah seluruh variabel independen secara bersama-sama (simultan) memiliki pengaruh yang signifikan terhadap variabel dependen. Uji statistik $\mathrm{F}$ dalam penelitian ini dilakukan dengan membandingkan nilai $F$ hasil perhitungan dengan $\mathrm{F}$ menurut tabel. $\mathrm{F}$ tabel pada tingkat signifikansi 0,05 untuk sample 58 adalah sebesar 2,282. Berikut ini adalah hasil uji statistik F dengan SPSS 22. 
Tabel 5

Hasil Uji Statistik F

ANOVA $^{\mathrm{a}}$

\begin{tabular}{|l|r|r|r|c|c|c|}
\hline \multicolumn{1}{|c|}{ Model } & Sum of Squares & df & Mean Square & F & Sig. & a \\
\hline $1 \quad$ Regression &, 081 & 6 &, 014 & 10,435 &, $000^{\mathrm{b}}$ &, 05 \\
Residual &, 066 & 51 &, 001 & & & \\
Total &, 147 & 57 & & & & \\
\hline
\end{tabular}

a. Dependent Variable: Lag2_Kinerja

b. Predictors: (Constant), Lag2_Klaster, Lag2_Leverage, Lag2_Opini, Lag2_IntergovernmentalRevenue, Lag2_UkuranLegislatif, Lag2_Size

Sumber: Data diolah dengan SPSS 22 (2017)

Tabel 5 menunjukan bahwa uji statistik $F$ menghasilkan nilai $F$ perhitungan sebesar 10,435 dengan tingkat signifikansi 0,000 . F hitung menunjukan angka yang lebih besar dari pada $\mathrm{F}$ tabel atau $10,435>2,282$ dan nilai signifikansi jauh lebih kecil dibandingkan dengan 0,05 sehingga dapat disimpulkan bahwa variabel opini audit, ukuran legislatif, intergovernmental revenue, size, Leverage, Klaster kemampuan keuangan daerah secara bersama-sama (simultan) berpengaruh signifikan terhadap kinerja keuangan pemerintah daerah. Hal ini menunjukan bahwa ketika kabupaten/kota di Provinsi Sumatera Selatan mendapatkan hasil opini audit Wajar Tanpa Pengecualian (WTP), memiliki kuantitas anggota DPRD yang banyak, tingkat ketergantungan (Intergovernmental Revenue) yang rendah, memiliki jumlah aset yang banyak, rasio leverage yang rendah, serta berada pada tingkat kemampuan keuangan daerah pada klaster A maka akan mempengaruhi baiknya kinerja keuangan daerah tersebut. Sehingga dalam penelitian ini $\mathbf{H}_{7}$ diterima.

Hasil penelitian ini mendukung penelitian yang dilakukan oleh Aziz (2016) dan Maiyora (2015) yang menunjukan hasil penelitian bahwa intergovernmental revenue dan ukuran daerah secara bersama-sama berpengaruh terhadap kinerja keuangan pemerintah daerah kabupaten/kota di Jawa Timur. Penelitian ini juga mendukung hasil penelitian yang dilakukan oleh Noviyanti dan Kiswanto (2016) dan Sudarsana dan Rahardjo (2013) bahwa fungsi pengawasan DPRD, intergovernmental revenue, dan ukuran daerah secara simultan berpengaruh terhadap kinerja keuangan pemerintah daerah kabupaten/kota di Indonesia. Penelitian yang dilakukan oleh Darmanto (2012) juga menunjukan hasil yang sama terhadap variabel size dan leverage yang berpengaruh secara simultan terhadap kinerja keuangan pemerintah daerah kabupaten/kota di Indonesia. Hasil pengujian penelitian ini juga sesuai dengan hasil penelitian Suryaningsih dan Sisdyani (2016) yang menyatakan bahwa secara simultan opini audit dan intergovernmental revenue berpengaruh terhadap kinerja keuangan pemerintah daerah. Hasil pengujian simultan untuk variabel ukuran daerah yang secara simultan berpengaruh terhadap kinerja keuangan pemerintah daerah juga mendukung hasil penelitian Renas (2014). Hasil penelitian untuk variabel opini audit, 
intergovernmental revenue, dan ukuran daerah yang berpengaruh secara simultan terhadap kinerja keuangan pemerintah daerah juga mendukung hasil penelitian yang dilakukan oleh Masdiantini dan Erawati (2016). Penelitian ini juga mendukung hasil penelitian Sesotyaningtyas (2012) yang menyatakan bahwa leverage, ukuran legislatif, dan intergovernmental revenue berpengaruh secara simultan terhadap kinerja keuangan pemerintah daerah. pernyataan yang sama diungkap oleh Marfiana dan Kurniasih (2013) bahwa ukuran daerah, intergovernmental revenue, ukuran legislatif, dan opini audit secara simultan berpengaruh terhadap kinerja keuangan pemerintah daerah.

\section{KESIMPULAN DAN SARAN Kesimpulan}

Berdasarkan pengujian dan hasil pembahasan yang telah dilakukan, maka dapat diambil kesimpulan bahwa variabel opini audit, ukuran legislatif, size, leverage, dan klaster kemampuan keuangan daerah secara parsial tidak berpengaruh signifikan terhadap kinerja keuangan pemerintah daerah dan variabel intergovernmental revenue berpengaruh negatif signifikan terhadap kinerja keuangan pemerintah daerah. Sedangkan secara simultan opini audit, ukuran legislatif, intergovernmental revenue, size, leverage, dan klaster kemampuan keuangan daerah secara bersama-sama memiliki pengaruh signifikan terhadap kinerja keuangan pemerintah daerah yang diukur dengan tingkat kemandirian daerah.

\section{DAFTAR PUSTAKA}

Aziz, Asmaul. 2016. Pengaruh Karakteristik Pemerintah Daerah terhadap Kinerja Keuangan Pemerintah Daerah (Studi pada Pemerintah Daerah Kabupaten/Kota di Jawa Timur). EKSIS Vol XI No 1.

BPK RI. 2015. BPK Wujudkan Kesejahteraan Rakyat Melalui Pemeriksaan Keuangan Negara. (http://www.bpk.go.id/news/bpkwujudkan-kesejahteraan-rakyatmelalui-pemeriksaan-keuangannegara, di akses pada 20 Januari 2017).

Darmanto, H. C. 2012. Pengaruh Population, Employment, Size dan Leverage terhadap Kinerja Keuangan Pemerintah Daerah di Indonesia. Skripsi Univeritas Sebelas Maret Surakarta.

Direktorat Jenderal Bina Keuangan Daerah. 2015. Postur APBD. (http://keuda.kemendagri.go.id/dati n/index/1/2015, diakses pada 20 Februari 2017)

Heriningsih, S., \& Marita, M. 2013. Pengaruh Opini Audit dan Kinerja Keuangan Pemerintah Daerah terhadap Tingkat Korupsi Pemerintah Daerah (Studi Empiris pada Pemerintah Kabupaten dan Kota di Pulau Jawa). Jurnal Buletin Ekonomi, 11(1), 1-86.

Mahmudi. 2016. Analisis Laporan Keuangan Pemerintah Daerah. 
Yogyakarta: Unit Penerbit dan Percetakan.

Marfiana, N., \& Kurniasih, L. 2013. Pengaruh karakteristik pemerintah daerah dan hasil pemeriksaan audit BPK terhadap kinerja keuangan pemerintah daerah kabupaten/kota. Sustainable Competitive Advantage (SCA), 3(1).

Maiyora, Gita. 2015. Pengaruh Karakteristik Pemerintah Daerah terhadap Kinerja Keuangan Pemerintah Daerah Kabupaten/Kota (Studi Empiris Kabupaten/Kota Di Pulau Sumatera). Jom FEKON, Vol. 2 No. 2, hal. 1-15.

Masdiantini, Putu Riesty dan Ni Made Adi Erawati. 2016. Pengaruh Ukuran Pemerintah Daerah, Kemakmuran, Intergovernmental Revenue, Temuan dan Opini Audit BPK pada Kinerja Keuangan. E-Jurnal Akuntansi Universitas Udayana, 14. hal. 1150-1182.

Muhayanah, Fisa Aprilia, dan Zulfikar. 2016. Pengaruh Pendapatan Asli Daerah, Dana Perimbangan Dan Belanja Modal Terhadap Kinerja Keuangan Pemerintah Daerah Kabupaten dan Kota Di Provinsi Jawa Tengah Tahun 2012-2013. Disertasi Universitas Muhammadiyah Surakarta.

Noviyanti dan Kiswanto. 2016. Pengaruh Karakteristik Pemerintah Daerah, Temuan Audit BPK terhadap Kinerja Keuangan Pemerintah
Daerah. Accounting Analysis Journal, 5(1).

Rai, I Gusti Agung. 2008. Audit Kinerja pada Sektor Publik. Jakarta: Salemba

Empat.

Renas dan Muid. 2014. Pengaruh Karakteristik Pemerintah Daerah dan Temuan Audit BPK terhadap Kinerja Pemerintah Daerah (Studi Pada Pemerintah Daerah Kabupaten/Kota di Provinsi Jawa Tengah Periode 2009-2011). Diponegoro Journal of Accounting, Volume 4, Nomor 3, Hal. 1-15.

Republik Indonesia. 2004. UndangUndang Republik Indonesia Nomor 33 Tahun 2004 tentang Perimbangan Keuangan antara Pemerintah Pusat dan Daerah. Sekretariat Negara. Jakarta.

Republik Indonesia. 2014. UndangUndang No. 23 Tahun 2014 tentang Pemerintah Daerah. Sekretariat Negara. Jakarta.

Republik Indonesia. 2014. Peraturan Pemerintah Nomor 29 Tahun 2014 tentang Sistem Akuntabilitas Kinerja Keuangan Instansi Pemerintah. Sekretariat Negara. Jakarta.

Republik Indonesia. 2007. Permendagri Nomor 21 Tahun 2007 tentang Pengelompokan Kemampuan Keuangan Daerah, Penganggaran dan Pertanggungjawaban Penggunaan Belanja Penunjang Operasional Pimpinan Dewan Perwakilan Rakyat Daerah serta 
Tata Cara Pengembalian

Tunjangan Komunikasi Intensif dan

Dana Operasional. Sekretariat Negara. Jakarta.

Saputra, S. C., Suwendra, I. W. dan Yudiaatmaja, F. 2016. Analisis Kinerja Keuangan Pemerintah Daerah dalam Pengelolaan Anggaran Pendapatan dan Belanja Daerah di Kabupaten Jembrana Tahun 2010-2014. e-Journal Bisma Universitas Pendidikan Ganesha, Vol.4.

Sesotyaningtyas, M. 2012. Pengaruh Leverage, Ukuran Legislatif, Intergovernmental Revenue dan Pendapatan Pajak Daerah terhadap Kinerja Keuangan Pemerintah Daerah. Accounting Analysis Journal, 1(1).

Siregar, S. R. 2012. Faktor-Faktor yang Mempengaruhi Pertimbangan Opini Auditor atas Laporan Keuangan Pemerintah Daerah
Istimewa Yogyakarta. Accounting Analysis Journal, 1(2).

Sudarsana, H. S., \& Rahardjo, S. N. 2013. Pengaruh Karakteristik Pemerintah Daerah dan Temuan Audit BPK Terhadap Kinerja Pemerintah Daerah (Studi pada Pemerintah Kabupaten/Kota di Indonesia). Diponegoro Journal Of Accounting Volume 2, Nomor 4, Hal 1-13.

Suryaningsih, N. M., \& Sisdyani, E. A. 2016. Karakteristik Pemerintah Daerah dan Opini Audit pada Kinerja Keuangan Pemerintah Daerah. E-Jurnal Akuntansi Universitas Udayana, Vol.15.2, 1453-1481.

Susilowati, S., \& Kristianto, D. 2016. Analisis Kinerja Keuangan Pemerintah Kabupaten Karanganyar Tahun Anggaran 2013-2015. Jurnal Akuntansi dan Sistem Teknologi Informasi vol.12 No. 2 229-237. 